\title{
Pengembangan Bahan Ajar Fisika Bermuatan Lifeskill untuk Siswa SMA
}

\author{
Susilawati, Nur Khoiri \\ Pendidikan Fisika IKIP PGRI Semarang \\ Surat-e: susilawati.physics@gmail.com
}

\begin{abstract}
Penelitian ini menjelaskan pengembangan bahan ajar fisika berbasis lifeskill pada kelas XI semester gasal. Bahan ajar disusun untuk membekali siswa dalam memahami pelajaran fisika yang terintegrasi dengan kecakapan hidup. Kecakapan hidup yang terintegrasi dalam buku ajar fisika ini meliputi kecakapan pribadi, sosial, akademis dan vokasional. Buku ajar fisika ini menyajikan beberapa aktivitas fisik dan mental siswa. Aktivitas yang memberikan pengalaman bagi siswa meliputi tugas pendahuluan materi, tugas diskusi, tugas eksperimen dan tugas proyek. Metode penelitian ini menggunakan metode research and development ( $R \& D$ ). Subjek penelitian ini melibatkan tim MGMP fisika SMA kota Semarang, sebagai tim validator bahan ajar dari praktisi pembelajaran di SMA dan tim validator ahli pendidikan fisika. Penelitian ini terdiri dari tahapan persiapan perangkat pembelajaran, tahap pelaksanaan penyusunan bahan ajar fisika dan tahapan evaluasi untuk menganalisis kekurangan dan kelebihan bahan ajar guna perbaikan bahan ajar fisika berbasis lifeskill sesuai dengan kebutuhan siswa dan tuntutan masyarakat. Hasil penelitian ini menghasilkan buku ajar fisika bermuatan lifeskills khususnya keterampilan kewirausahaan yang layak digunakan oleh siswa SMA.
\end{abstract}

Kata kunci: bahan ajar, lifeskill, keterampilan kewirausahaan, pembelajaran fisika

\section{Pendahuluan}

Tuntutan perkembangan terapan pengetahuan dan teknologi pada saat ini mengarah pada persaingan global dan mengupayakan persediaan energi terbarukan. Untuk kondisi tersebut, kecakapan hidup siswa sekolah menengah harus dilatih dalam proses pembelajaran. Mengingat pelajaran fisika merupakan pelajaran yang berorientasi pada perkembangan ilmu pengetahuan dan teknologi yang menyajikan berbagai aktivitas scientific.

Dalam memfasilitasi siswa sekolah menengah dibutuhkan keterampilan-keterampilan yang membekali siswa tersebut untuk mampu mempertahankan eksistensi dirinya dalam kehidupan bermasyarakat (Danish, 1997). Siswa sekolah menengah membutuhkan pengakuan tentang keberadaan dirinya. Oleh karena itu, bahan ajar yang menyajikan materi fisika terintegrasi dengan aktivitas kecakapan hidup sangat penting untuk membekali siswa sekolah menengah dalam mempersiapkan kehidupan masa depan yang cemerlang. Beberapa alasan perlunya mengintegrasikan lifeskill dalam pembelajaran fisika, yaitu: (I) kegiatan eksperimen dan demonstrasi menjadi kegiatan dominan dalam proses pembelajaran fisika; (2) Pemecahan masalah menjadi tujuan pembelajaran dan pengalaman belajar yang harus dimiliki siswa; (3) banyak konsep dan keterampilan yang dibutuhkan dalam kehidupan sehari-hari berkaitan dengan konsep pembelajaran.

Hasil wawancara dengan guru Sekolah Menengah Atas di kota semarang diperoleh informasi bahwa lifeskill memberikan makna dan nilai guna dalam mempelajari fisika. Lifeskill secara implementatif melatih siswa untuk mempunyai jiwa kepemimpinan, keterampilan kewirausahaan dan mempunyai kepribadian yang baik dapat diterima dalam kehidupan bermasyarakat. Ada beberapa keluhan dari guru SMA di kota mengenai persiapan dan pelaksanaan pembelajaran fisika yang bermuatan lifeskill yaitu sangat membutuhkan waktu yang lebih untuk merencanakan proses pembelajaran. Oleh karena itu, ketika bahan ajar fisika disusun secara kolaboratif oleh praktisi pendidikan maka memungkinkan disambut dengan hangat oleh guru-guru SMA di kota Semarang.

Berdasarkan data hasil studi pendahuluan kebutuhan lifeskill terintegrasi dengan pembelajaran fisika diperoleh tanggapan dari guru-guru fisika MGMP fisika kota Semarang. Kebutuhan siswa pada masing-masing 
keterampilan antara lain terhadap kecakapan personal mencapai 89\%. Kebutuhan siswa akan kecakapan sosial mencapai 85\%. Kebutuhan siswa akan kecakapan vokasional mencapai 77\%. Kebutuhan siswa akan kecakapan akademis mencapai 86\% (Susilawati, 2013).

Dalam proses pembelajaran, penyajian bahan ajar menjadi kompetensi utama seorang guru dalam mendesain aktivitas dan kemampuan berpikir seperti apa yang harus dikuasai siswa (Dick, 1990). Dalam bahan ajar, guru telah memastikan sejauh mana tingkat kesiapan siswa dalam pencapaian tujuan dan pengalaman belajar (Blanchard, 199I). Untuk menambah pengalaman siswa, guru harus selalu aktif dan kreatif berperan sebagai fasilitator yang inspiratif.

Bahan ajar merupakan segala bentuk bahan yang digunakan untuk membantu guru dalam melaksanakan kegiatan belajar mengajar dikelas (Goudas, 2006). Bahan yang dimaksud bisa berupa bahan tertulis (cetak) maupun bahan tidak tertulis (non cetak/online). Bahan yang termasuk sumber informasi, alat dan teks yang diperlukan guru dalam menyajikan materi dan keterampilan yang harus dimiliki siswa (Yin, 2003). Sumber informasi materi dan kegiatan ini terdiri dari seperangkat materi yang disusun secara sistematis baik tertulis maupun tidak tertulis sehingga tercipta lingkungan atau suasana yang memungkinkan siswa untuk belajar (Levin, 2008).

Beberapa asumsi tentang arti penting kedudukan bahan ajar khususnya, rancangan pembelajaran pada umumnya, yaitu: membantu belajar secara perorangan; (2) memberikan keleluasaan penyiapan pembelajaran jangka pendek dan jangka panjang; (3) rancangan bahan ajar yang sistematis memberikan pengaruh yang besar bagi perkembangan sumber daya manusia secara perorangan; (4) memudahkan pengelolaan proses belajar mengajar secara sistematis; dan (5) memudahkan belajar (Harijanto, 1997). Sebagai fokus pembelajaran, bahan ajar mempunyai struktur dan urutan yang sistematis, menjelaskan tujuan pembelajaran yang akan dicapai, memotivasi siswa untuk belajar, mengantisipasi kesulitan siswa, menyajikan banyak latihan dan rangkuman.

\section{Metode Penelitian}

Penelitian ini menggunakan penelitian R \& D (Research and Development). Penelitian R \& D digunakan untuk mendesain produk atau prosedur yang teruji secara sistematis di lapangan, dievaluasi dan dikembangkan sedemikian rupa sehingga memenuhi kriteria efektivitas, kualitas atau kemiripan dengan suatu standar (Gall, 2003). Pegembangan bahan ajar fisika melalui tahapan penelitian dan pengembangan. Penelitian ini bertujuan untuk mengembangan bahan ajar fisika berbasis lifeskill yang diharapkan mampu membekali siswa untuk mendapatkan dan melatih kecakapan hidup siswa sekolah menengah. Alur penelitian ini melalui serangkaian tahapan penelitian seperti pada Gambar I.

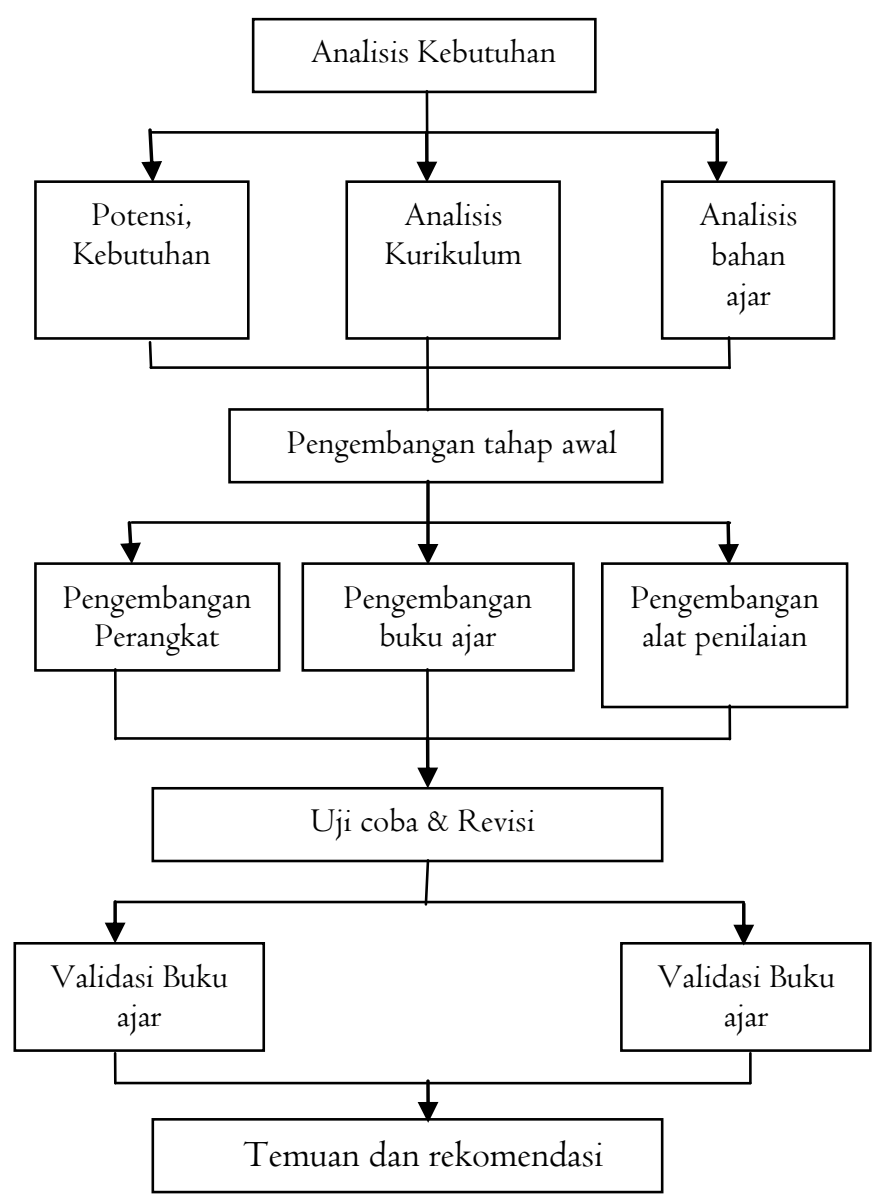

Gambar I. Tahapan Penelitian Pengembangan Bahan Ajar

Teknik pengumpulan data terdiri dari lembar validasi buku ajar fisika berbasis lifeskill dan lembar wawancara. analisis kebutuhan dan potensi siswa dilakukan dengan observasi. Analisis kurikulum dan analisis bahan ajar fisika dilakukan dengan kegiatan telaah kurikulum dan buku ajar fisika. kegiatan selanjutnya mengembangkan bahan ajar fisika berbasis lifeskill. Setelah dilakukan penyusunan buku ajar fisika kelas XI semester I dilakukan validasi terhadap buku ajar tersebut. Adapun tahapan penyusunan berikut pengembangan bahan ajar seperti Gambar 2 .

Teknik analisis data dilakukan dua tahapan yaitu, pertama: analisis data hasil wawancara dilakukan analisis deskriptif kualitatif untuk mendapatkan informasi mengenai kecakapan hidup yang harus dimunculkan pada setiap konsep fisika dan aktivitas pembelajaran. Kedua, analisis 
lembar validasi bahan ajar fisika dianalisis dengan perhitungan prosentase sebagai berikut:

$86 \%-100 \%$ : sangat baik/ sangat tinggi

$76 \%-85 \%$ : baik/ tinggi

$66 \%-75 \%$ : cukup/sedang

$56 \%-65 \%$ : kurang/ rendah

$0 \%-55 \%$ : sangat kurang/ sangat rendah

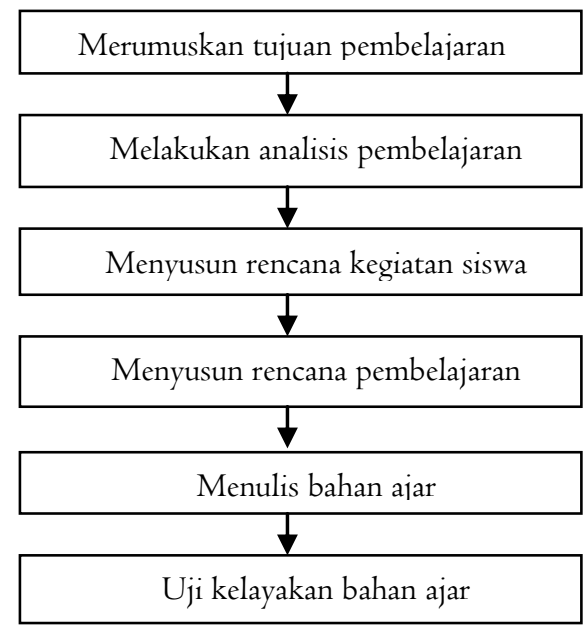

Gambar 2. Proses penyusunan bahan ajar berbasis lifeskill

\section{Hasil dan Pembahasan}

Analisis kurikulum dilakukan untuk mengidentifikasi materi esensial dan materi yang banyak ditemui dalam kehidupan sehari-hari. Analisis kurikulum dengan menjabarkan kompetensi dasar, indikator, materi pelajaran, dan kegiatan pembelajaran. Analisis kurikulum dilakukan bertujuan untuk mengembangkan aktivitas dan pengalaman belajar siswa.

Sumber belajar diidentifikasi melalui kegiatan wawancara. berdasarkan hasil wawancara diperoleh prosentase sebesar $75 \%$ siswa belajar dari buku paket yang digunakan oleh guru. Prosentase sebesar 80\% siswa belajar dari lembar kerja siswa (LKS). Prosentase siswa yang menggunakan media internet sebagai sumber belajar sebesar 56\%. Penggunaan jurnal penelitian sebagai sumber belajar sebanyak $2 \%$. Penggunaaan surat kabar dan majalah sebagai sumber belajar sebanyak 5\%. Data penggunaan sumber belajar dan motivasi belajar siswa dapat dilihat pada Tabel I.

Tabel I. Hasil Wawancara Penggunaan Sumber Belajar dan Motivasi Belajar Siswa

\begin{tabular}{llcc}
\hline No. & Sumber Belajar & $\begin{array}{c}\text { Motivasi } \\
\text { Belajar }\end{array}$ & Prosentase \\
\hline
\end{tabular}

\begin{tabular}{llcc}
\hline I. & Buku Paket & Sedang & 75 \\
2. & Lembar Kerja Siswa & Tinggi & 80 \\
3. & Media Edukasi Online & Tinggi & 56 \\
4. & Jurnal, Artikel ilmiah & Rendah & 2 \\
5. & Surat Kabar & Rendah & 5 \\
\hline \hline
\end{tabular}

Berdasarkan hasil observasi di sekolah mitra praktik pengalaman lapangan (PPL) rata-rata sekolah menggunakan Lembar Kerja Siswa sebagai bahan ajar yang utama. Sedangkan buku paket digunakan sebagai sumber ketika ditemukan konsep yang sulit dikuasai oleh siswa. Selain itu, buku paket digunakan apabila ada soal-soal latihan yang memerlukan penjelasan lebih luas dan penjelasan tersebut tidak ditemukan di lembar kerja siswa. Lembar kerja siswa mempunyai prosentase tertinggi sebagai bahan ajar, karena lembar kerja siswa menjadi pegangan wajib bagi siswa pada sebagian besar sekolah.

Lembar kerja siswa memberikan lembar isian yang harus dilengkapi oleh siswa. Untuk melengkapi isian ini, siswa harus memahami konten materi. Selain itu, terdapat Lembar Kegiatan Siswa yang berisi rangkaian kegiatan ilmiah untuk mendapatkan data berdasarkan hasil pengamatan maupun hasil praktikum.

Buku paket merupakan buku yang wajib dimiliki oleh siswa sebagai anjuran dari guru dan orang tua siswa untuk sumber belajar. Buku paket disusun oleh tim-tim profesional, orang yang secara praktis menekuni bidang tersebut. Buku paket fisika disusun oleh guru fisika yang profesional secara praktis atau ahli fisika. Buku paket bersumber dari buku teks dan berpedoman pada kurikulum yang berlaku. Buku teks memberikan konten materi yang teruji kebenarannya. Kurikulum memberikan panduan pokok-pokok materi yang harus dijabarkan secara detail dan pemahaman yang mendalam oleh penulis.

Artikel ilmiah sebagai sumber bahan ajar yang aktual (mutakhir). Artikel ilmiah memberikan hasil pemikiran dan hasil penelitian yang relevan dengan bidangnya masingmasing, terutama di bidang pendidikan. Bahan ajar yang bersumber dari artikel ilmiah tlah di judgment kebenaran konten materi, sistematika dan kedalaman materi. Akan tetapi, motivasi penggunaan sumber dan media pembelajaran terbesar adalah saran dan contoh dari guru. Pada umumnya, guru mengajar dan menyelenggarakan pembelajaran dengan menggunakan buku paket dan LKS sebagai sumber belajar. Siswa tidak pernah didampingi dan diberi pengarahan untuk mencari artikel ilmiah dan mencari pengetahuan bersumber pada artikel ilmiah. Sehingga penggunaan artikel ilmiah sebagai bahan ajar mempunyai prosentase yang paling rendah.

Sumber terbitan berkala seperti surat kabar memberikan kabar terkini mengenai perkembangan sains dan teknologi. 
Sumber pengetahuan yang berasal dari surat kabar memberikan pengetahuan dengan penyajian bahasa yang mudah dimengerti. Surat kabar hanya digunakan siswa sekedar untuk mengisi waktu luang dan ada beberapa siswa yang benar-benar senang membaca. Surat kabar belum menjadi bagian dari sumber bahan ajar yang digunakan oleh guru dan siswa di sekolah.

\section{Hasil validasi ahli (praktisi pendidikan)}

Hasil validasi oleh praktisi pembelajaran fisika menunjukkan bahwa bahan ajar berbasis lifeskill memenuhi dalam hal kebenaran content dan kebutuhan siswa. Prosentase rata-rata setiap indikator penilaian ahli dapat dilihat pada Gambar 3.

Analisis setiap indikator validasi bahan ajar prosentase kelayakan untuk berdasarkan penilaian praktisi mencapai $84,25 \%$. Indikator validasi bahan ajar meliputi: (I) isi yang disajikan dengan kelayakan 85\%; (2) bahasa dengan kelayakan $87 \%$; (2) struktur modul dengan kelayakan $90 \%$, dan (4) organisasi materi dengan kelayakan 75\%. Sedangkan hasil penilaian berdasarkan uji ahli mencapai $8 \mathrm{I} \%$. Indikator validasi bahan ajar meliputi: (I) isi yang disajikan dengan kelayakan 80\%; (2) bahasa dengan kelayakan $83 \%$; (2) struktur modul dengan kelayakan $82 \%$, dan (4) organisasi materi dengan kelayakan $80 \%$. Isi yang disajikan dalam bahan ajar fisiska berbasis lifeskill meliputi tugas pendahuluan materi, tugas diskusi, tugas eksperimen dan tugas proyek. Rangkaian penugasan ini untuk membimbing siswa mengembangkan kecakapan pribadi, sosial, akademis dan vokasional.

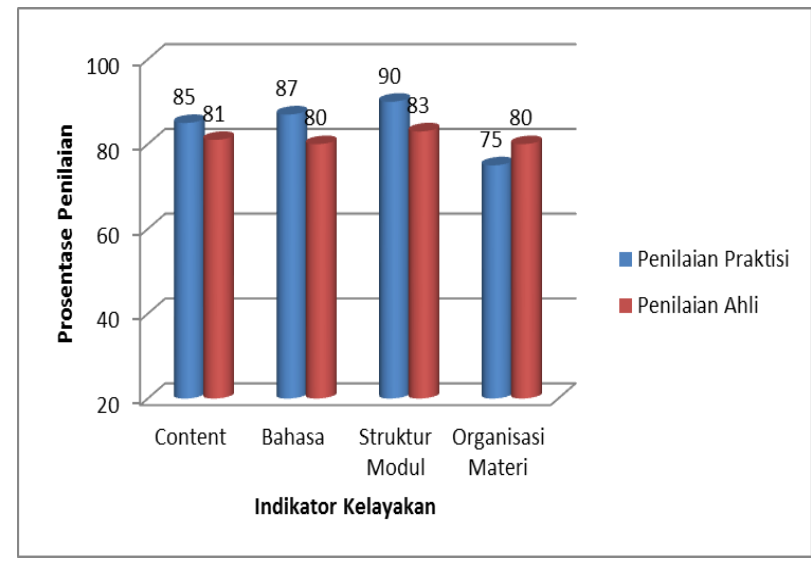

Gambar 3. Prosentase Rata-rata Setiap Indikator Penilaian Ahli

Berdasarkan hasil analisis rata-rata deskriptor penilaian ahli di atas dapat dijabarkan dalam beberapa indikator, pertama indikator isi yang disajikan (content) antara lain:
(I) materi disajikan secara sistematis (80\%); (2) merupakan materi/tugas yang esensial (83\%); (3) masalah yang diangkat sesuai dengan tingkat kognisi siswa (85\%); (4) setiap kegiatan yang disajikan dapat menumbuhkan rasa ingin tahu siswa (87\%); (5) kegiatan yang disajikan dapat menumbuhkan motivasi (90\%); dan (6) penyajian dilengkapi dengan gambar dan ilustrasi $(85 \%)$. Berdasarkan isi yang disajikan, materi disampaikan secara urut mulai dari ilustrasi yang sederhana sampai pada kegiatan pemecahan masalah. Materi yang disajikan hanya materi yang esensial saja sehingga materi tidak terlalu banyak. Masalah yang disajikan lazimnya berasal dari pengalaman sehari-hari siswa SMA. Kegiatan yang disajikan dalam bahan ajar diawali dengan rangkaian pertanyaan yang membuat siswa termotivasi untuk mencari jawabannya. Ilustrasi dan gambar yang menarik mengupayakan penjelasan konsep secara fisis.

Kedua, indikator bahasa, antara lain: (I) penggunaan bahasa sesuai dengan EYD (90\%); (2) bahasa yang digunakan sesuai dengan tingkat perkembangan kognisi siswa (86\%); (3) bahasa yang digunakan komunikatif (88\%); (4) kalimat yang digunakan jelas dan mudah dimengerti (83\%); (5) kejelasan petunjuk atau arahan (90\%). Bahasa yang digunakan dalam bahan ajar ini sangat membimbing siswa untuk dapat belajar mandiri dengan mengikuti petunjuk di setiap kegiatan yang disajikan.

Ketiga, indikator struktur modul, antara lain: (I) organisasi penyajian secara umum (92\%); (2) tampilan umum menarik (89\%); (3) keterkaitan yang konsisten antara bahasa dan materi (9I\%). Keempat, indikator organisasi materi, antara lain: (I) cakupan materi (70\%); (2) kejelasan dan urutan materi (75\%); dan (3) ketepatan materi dengan kompetensi inti (81\%). Berdasarkan tampilan modul, penyajian yang digunakan sudah familiar digunakan oleh bahan ajar yang biasa digunakan siswa. Tampilan yang menarik dan bahasa yang mudah dipahami sangat relevan dengan penyampaian materi. Organisasi materi yang meliputi cakupan materi, urutan materi, dan ketepatan materi dengan kompetensi inti direkomendasikan oleh praktisi pembelajaran telah memenuhi standar buku paket yang dapat menuntut pembelajaran siswa.

Beberapa masukan mengenai bahan ajar yang digunakan yaitu mengenai kompetensi vokasional sebaiknya dimunculkan setiap konsep bahasan. Warna dan ilustrasi contoh dalam kehidupan sehari-hari diajukan sebagai bahan diskusi. Setiap latihan soal hendaknya diberikan tuntunan jawaban. Menurut Spillane et al bahan ajar harus disajikan untuk membantu siswa dalam mencari pengalaman belajar secara mandiri (Spillane, 2004). 


\section{Kesimpulan}

Bahan ajar fisika berbasis lifskill ini layak digunakan dalam pembelajaran fisika. kelayakan dapat dlihat dari hasil penilaian validator baik dari praktisi pendidikan maupun uji ahli mengenai isi yang disajikan, aspek bahasa yang digunakan, struktur modul dan organisasi materi. Bahan ajar ini dinyatakan mampu memenuhi perkembangan tuntutan terapan pengetahuan dan teknologi yang mengarah pada persaingan global. Pada bahan ajar ini terdapat kecakapan personal, kecakapan sosial, kecakapan akademis dan kecakapan vokasional yang harus dilatih pada siswa Sekolah Menengah Atas. Kecakapan tersebut tertuang dalam aktivitas yang diberikan berupa pengalaman bermakna bagi siswa meliputi tugas pendahuluan materi, tugas diskusi, tugas eksperimen dan tugas proyek.

\section{Ucapan Terima Kasih}

Penelitian ini dilaksanakan dengan dana penelitian desentralisasi hibah bersaing DIKTI tahun anggaran 20I320I4. Penelitian ini dilaksanakan di program studi pendidikan fisika dan bekerjasama dengan MGMP Fisika kota Semarang. Pelaksanaan penelitian ini mendapat pengarahan dan monitoring dari LPPM IKIP PGRI Semarang. Produk bahan ajar pada penelitian ini di telaah oleh validator dari praktisi dan ahli pendidikan fisika.

\section{Kepustakaan}

Blanchard, J. (2002). Teaching and targets: Self-evaluation and school improvement. London: RoutledgeFalmer.

Danish, S.J., \& Nellen, V.C., New roles for psychologists: Teaching life skills, Quest, 1997.

Dick W \& Carey, L. (1990). The Systematic Design of Instructional. Third Edition. USA: Harper Collins Publisher

Gall, M.D., Gall, J.P., \& Borg, W.R., Educational Research an Education Seventh Edition, Pearson Education, Inc, 2003

Goudas, et al, The Effectiveness of Teaching a Life Skills Program in a Physical Education Context, European Journal of Psychology of Education, vol. 4, 2006, pp. 429-438

Harijanto, M., Pengembanagan Bahan Ajar untuk Peningkatan Kualitas Pembelajaran Program Pendidikan Pembelajaran Sekolah Dasar, Didaktika, vol. 2, 2007, pp. 216-226.

Levin, B., How to change 5000 schools: A practical and positive approach for leading change at every level. Cambridge University Press: 2008.

Spillane, J., Halverson, R., \& Diamond, J., Towards a theory of leadership practice: A distributed perspective, Journal of Curriculum Studies, vol. 36, no. 1, 2004, pp. 3-14.
Susilawati \& Khoiri, N., Analisis Kebutuhan Pembelajaran Fisika Berbasis Lifeskill Bagi Siswa SMA Kota Semarang, Prosiding 1st Diponegoro Physics Conference, ISBN 978602-18940-1-9, Semarang, November 2013

Yin, R. K., Case study research: Design and methods, Sage, 2003 